\title{
A solitary rough-toothed dolphin (Steno bredanensis) in a superport area on northern Rio de Janeiro State, SE Brazil
}

\author{
Ana Paula Madeira Di Beneditto ${ }^{1 *} \mathbb{D}$ \& Salvatore Siciliano ${ }^{2} \mathbb{D}$ \\ ${ }^{1}$ Universidade Estadual do Norte Fluminense Darcy Ribeiro, Centro de Biociências e Biotecnologia, \\ Laboratório de Ciências Ambientais, Campos dos Goytacazes, RJ, Brasil. \\ ${ }^{2}$ Fundação Oswaldo Cruz, Laboratório de Biodiversidade, Rio de Janeiro, RJ, Brasil. \\ ${ }^{*}$ Corresponding author: Ana Paula Madeira Di Beneditto,e-mail: anadibeneditto@gmail.com
}

BENEDITTO, A. P., SICILIANO, S. A solitary rough-toothed dolphin (Steno bredanensis) in a superport area on northern Rio de Janeiro State, SE Brazil. Biota Neotropica 20(3): e20201028. https://doi.org/10.1590/16760611-BN-2020-1028

\begin{abstract}
The solitary behavior is an unusual and peculiar behavior reported in a few sociable dolphin species. This study presents the solitary behavior of an adult rough-toothed dolphin, Steno bredanensis, in the Açu Superport ( $21^{\circ} 49^{\prime}$ S; $\left.041^{\circ} 00^{\prime} \mathrm{W}\right)$, northern Rio de Janeiro State, SE Brazil. Data about the dolphin were obtained from mobile phone videos and reports by local professionals. Probably, the same dolphin was there since 2017-2018 up to April 2020 (at least). In general, the solitary dolphin swims next to supply boats navigating along the port internal channel, and it rarely continues towards open sea. The dolphin plays with buoys and containment barriers, rubs itself against hulls, and bow-rides and jumps. There is no report of people swimming with this solitary dolphin, touching it, or offering it food in the Açu Superport. Thus, there seems to be no threats to the animal's integrity locally.

Keywords: Solitary Dolphin; Behavior; Delphinidae; Atlantic Ocean.
\end{abstract}

\section{Um golfinho de dentes-rugosos (Steno bredanensis) solitário em área de superporto no norte do Estado do Rio de Janeiro, SE Brasil}

Resumo: O comportamento solitário é um comportamento incomum e peculiar relatado em poucas espécies sociáveis de golfinhos. Este estudo apresenta o comportamento solitário de um golfinho de dentes-rugosos adulto,

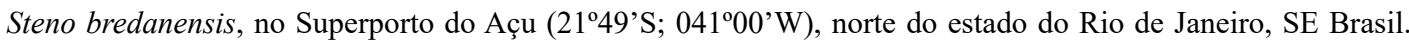
Os dados sobre o golfinho foram obtidos a partir de vídeos de telefones móveis e relatos de profissionais locais. Provavelmente, o mesmo golfinho estava lá desde 2017-2018 até abril de 2020 (pelo menos). Em geral, o golfinho solitário nada próximo aos barcos de apoio enquanto eles navegam pelo canal interno do porto, e raramente continua em direção ao mar aberto. O golfinho brinca com boias e barreiras de contenção, esfrega-se contra os cascos e executa comportamentos de saltos. Não há relato de pessoas nadando com esse golfinho solitário, tocando nele ou oferecendo comida a ele no Superporto do Açu. Dessa forma, parece que não há ameaças à integridade do animal localmente.

Palavras-chave: Golfinho Solitário; Comportamento; Delphinidae; Oceano Atlântico. 


\section{Introduction}

Solitary dolphins are social species living apart from their own groups, with little or even no contact with conspecifics, and a high tendency to socialize with humans in different levels, such as touching, social, sexual and playing behaviors (Wilke et al. 2005). Wilke et al. (2005) raised some reasons to explain why social dolphins become solitary and sociable towards people (e.g., food availability, loss of habitat, lack of connectivity between dolphin populations, predation risk, and dolphin's personality); but until now these reasons remain somewhat speculative. Nunny \& Simmonds (2019) summarized the current knowledge regarding solitary delphinids and monodontids (ten different species), detailing cases recorded since 2008 worldwide. The most frequent species are the bottlenose dolphins, Tursiops truncatus (Montagu 1821) and T. aduncus (Ehrenber 1833). More recently, the solitary behavior of the rough-toothed dolphin, Steno bredanensis (Lesson 1828), was reported from a juvenile male near a Brazilian Navy base in Sepetiba Bay (22 ${ }^{\circ} 54^{\prime}$ S $-23^{\circ} 04^{\prime}$ S $)$, southern Rio de Janeiro State, SE Brazil (Flach \& Dias 2020; Maciel et al. 2020).

The rough-toothed dolphin inhabits tropical, subtropical and warm-temperate waters in all three major oceans, mostly between $40^{\circ} \mathrm{N}$ and $35^{\circ} \mathrm{S}$. This species usually occurs in oceanic waters deeper than $1,000 \mathrm{~m}$, but also in shallower waters (until $30 \mathrm{~m}$ or less) (West et al. 2011; Jefferson 2018; Lodi \& Maricato 2020). This species lives in relatively small groups, mostly ranging from 10-20 individuals, although larger groups up to 50 or more individuals and mixed groups in association with other species have been documented (Jefferson 2018). The conservation status of the rough-toothed dolphin ('least concern'; Kiszka et al. 2019) suggests that, globally, the populations are not threatened; however, considering the anthropogenic activities and disturbances in the dolphins' habitats, such as fisheries, ports, chemical and sound pollutions, marine debris and climate change, monitoring of their populations is recommended (Jefferson 2018).

In northern Rio de Janeiro State $\left(21^{\circ} \mathrm{S}-22^{\circ} \mathrm{S}\right)$, past surveys on the relationship between fisheries and dolphins indicated that the rough-toothed dolphin was occasionally captured in gillnet operations practiced up to the $50 \mathrm{~m}$ depth contour (Di Beneditto et al. 1998; Di Beneditto 2003). In this region, it is likely that the rough-toothed dolphin occurs in deeper waters, far from the coastline and gillnet fisheries; however, inhabiting a deeper environment does not necessarily mean that the species is far from anthropogenic influences. The northern Rio de Janeiro State faced an economic boom in the 1970s, when offshore oil deposits were discovered in deep waters of the Campos Basin, a sedimentary basin that covers approximately $100,000 \mathrm{~km}^{2}$ from $19^{\circ} \mathrm{S}$ to $23^{\circ} \mathrm{S}$ and corresponds to $70-80 \%$ of Brazilian domestic production of oil and gas (Rodriguez \& Suslick 2009). These local port activities provide logistics to the oil and gas production that have been growing since then, affecting coastal areas (Zappes et al. 2016). In this context, recent assessments have indicated a considerable burden of contaminants in populations of rough-toothed dolphins along the SE Brazilian coast (Monteiro et al. 2019, 2020).
This study presents the solitary behavior of a sociable rough-toothed dolphin in a port area on northern Rio de Janeiro State, Brazil. Our purpose is to contribute to the understanding of this unusual and peculiar behavior reported in a few species worldwide.

\section{Materials and Methods}

In December 2019, we received a report from a citizen (S.R. Gomes) from Atafona village $\left(21^{\circ} 37^{\prime} \mathrm{S} ; 041^{\circ} 01^{\prime} \mathrm{W}\right)$ regarding a solitary dolphin that was wandering the Açu Superport area $\left(21^{\circ} 49^{\prime} \mathrm{S} ; 041^{\circ} 00^{\prime} \mathrm{W}\right)$ (Figure 1). A superport is a large port capable of accommodating very large ships, especially supertankers of 100,000 tons or more. The Açu Superport is a private port that started to be built in 2008 and it has been in operation since 2014. Marine traffic density maps demonstrate significant increase in ships movement since 2016 (available at: https://www.marinetraffic.com/en/ais/home/centerx:-41.0/ centery:-21.8/zoom:11).

The Açu Superport is the main hub for oil and gas in Brazil, providing logistics to offshore activities in Campos Basin. The Açu Superport area encompasses $90 \mathrm{~km}^{2}$ subdivided into two large terminals that operate $24 / 7$. The Terminal 1 is the offshore terminal with five piers for handling iron ore and oil. The Terminal 2 is the onshore terminal installed around an internal channel with seven Private Use Terminals (PUTs). The PUTs handle solid and liquid bulk cargoes and provide logistics for oil and gas exploration activities. The internal channel of Terminal 2 has an "L" shape and two piers, north and south, protecting its entrance (Figure 1). The channel is $6.5 \mathrm{~km}$ long, $270 \mathrm{~m}$ wide and $14 \mathrm{~m}$ deep in the east-west section, and $120 \mathrm{~m}$ wide and $10 \mathrm{~m}$ deep in the north-south section (available at: https:// portodoacu.com.br/wp-content/uploads/2018/02/InformacoesPortuarias-T2.pdf).

In February 2020, we were introduced to four professionals (three sailors and one diver), residents from Atafona village, who work in supply boats in the Açu Superport and have personally interacted with the dolphin. They sent us mobile phone videos and agreed to provide information about the dolphin after we explained the aims of the study.

The interviewees answered the same questionnaire, with open questions about the routine in the Açu Superport, since when the solitary dolphin has been there, the dolphin's behavior, and if they swim with the dolphin, touch it or offer food to it. Each interview was conducted individually to avoid interference during the dialogue. Since the answers of the four interviewees were convergent, we considered them as a single narrative about the presence of the solitary roughtoothed dolphin in the Açu Superport, including its behavior. Only the specific reports made by the diver dealing with his underwater experience with the dolphin were highlighted from the answers. 

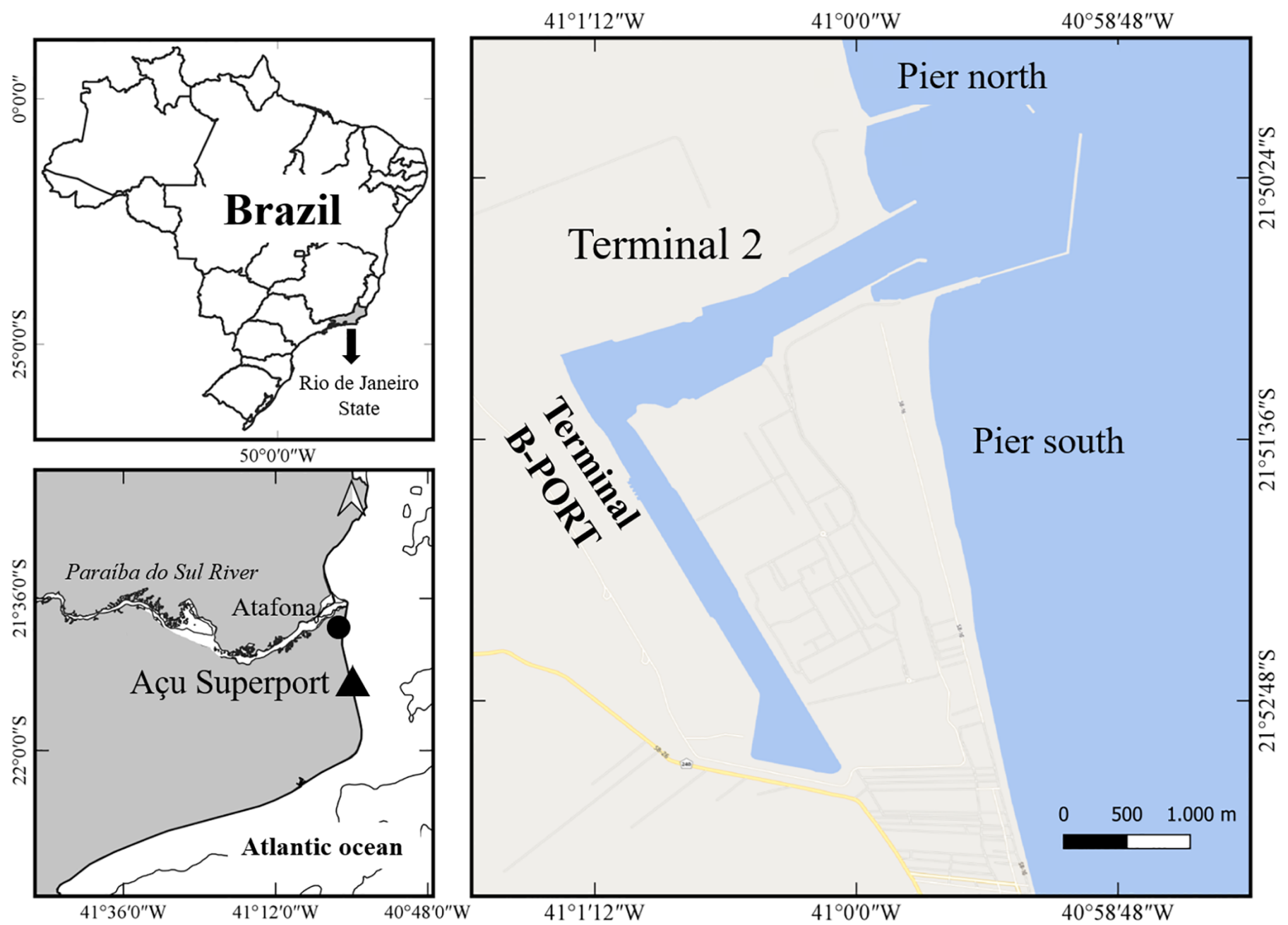

Figure 1. Location of the Açu Superport in northern Rio de Janeiro State, SE Brazil, and the Terminal 2 where the solitary rough-toothed dolphin has lived since 2017-2018.

\section{Results and Discussion}

The solitary dolphin was identified as a rough-toothed dolphin, Steno bredanensis (Cetartiodactyla, Delphinidae) according to mobile phone videos taken by the interviewees (Figure 2). The body features with taxonomical importance noted in the images were: i) no prominent melon and no crease between the beak and forehead, ii) forehead and sides of the head sloping smoothly onto a long and slender beak, iii) dark grey color forming a narrow cape or band along the back with white below, iv) light-colored blotches on the body, and v) white lips and lower jaw (Figure 2) (Jefferson 2018). Since young rough-toothed dolphins have a muted color pattern and generally lack the white blotches on the body (Miyazaki \& Perrin 1994), we can infer that this solitary dolphin is an adult individual.

Since 2017, the four interviewees have worked regularly on supply boats at Terminal 2 of the Açu Superport. The three sailors were former fishers at Atafona village, and one of them is a professional diver. They usually stay a two-week period on board, in the port area, and come back home for a resting period of another two-week. The supply boat can be demanded both day and night, according to ships and/or tugs movement. Thus, the interviewees navigate through the internal channel of Terminal 2 and adjacent open marine waters daily.
According to the interviewees, the solitary dolphin was seen for the first time near the Açu Superport between 2017 and 2018, and it has been there until the organization of the study data (April 2020). Indeed, there are no previous videos or photos to prove by photo identification method, for instance, that it is the same dolphin from 2017-2018 until 2020. We had the same report made by four different interviewees and the literature data that describe solitary dolphins as individuals with restrict movements to a small area, with time interval of site fidelity from few weeks to months, or even decades (20-40 years) (Müller \& Bossley 2002, Nunny \& Simmonds 2019). Thus, we assumed that this record is probably from the same dolphin with local site fidelity over two years up to now.

The dolphin frequently swims next to the supply boat while navigating along the internal channel of Terminal 2, but it remains close to the access channel, between the piers north and south, even if the boat continues towards open sea (Figure 1). Then, the solitary dolphin returns to the Terminal 2. This route is done during daytime, but it has already been recorded at night. The dolphin frequently displays bow-riding and jumping behaviors near the supply boat (Figures 2). These aerial behaviors are common in free-ranging rough-toothed dolphins, as reported off La Gomera, Canary Islands, in a long survey (Ritter 2002). 


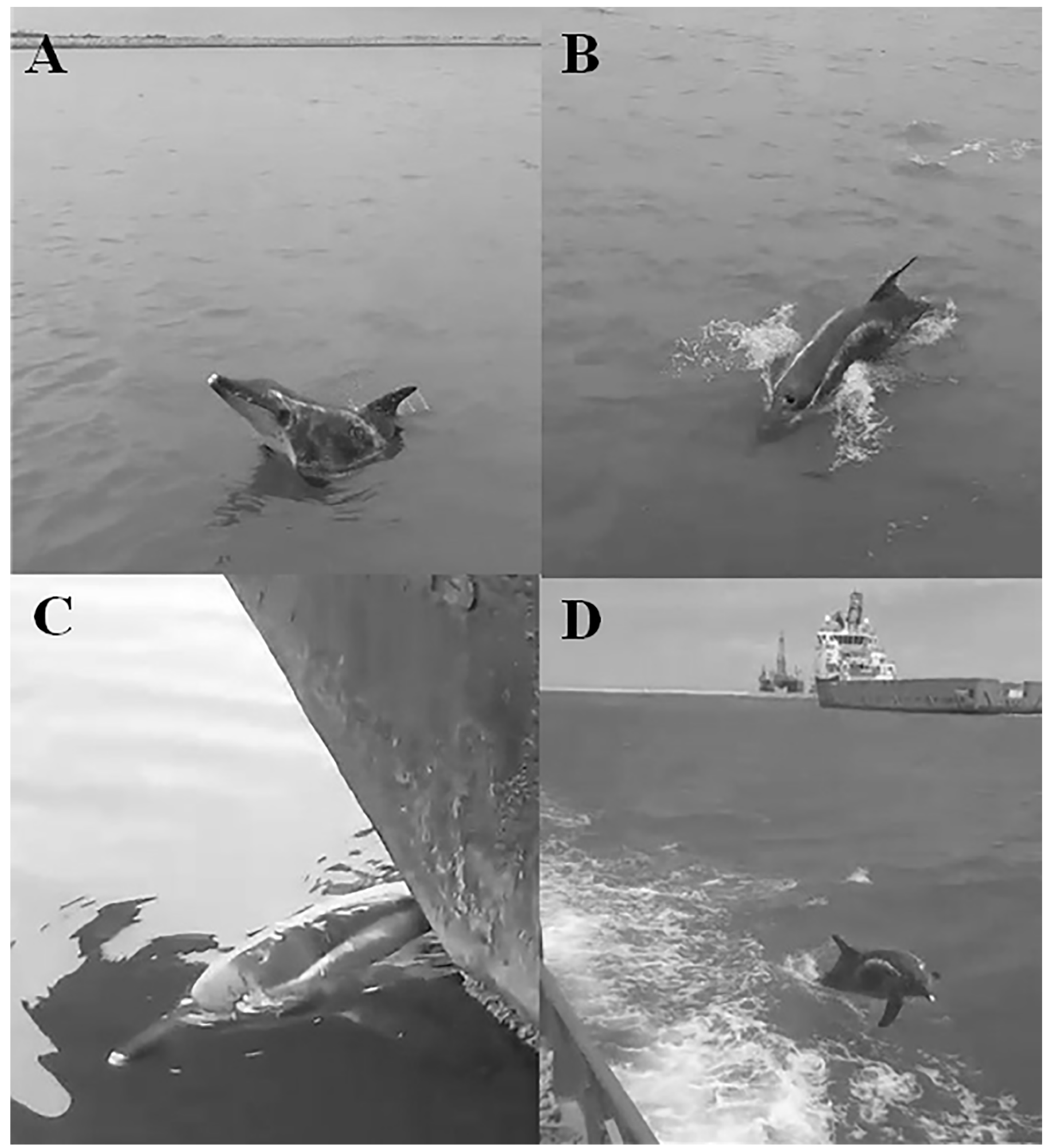

Figure 2. The solitary rough-toothed dolphin in the Açu Superport. Images available from mobile phones videos used by the interviewees in December 2019. A and B) Dolphin swimming next to the supply boat; C) Dolphin rubbing itself against a hull inside the Terminal 2; and D) Dolphin bow-riding next to the supply boat - in the background a tug and the oil platform anchored near the pier south (until February 2020).

The interviewees also reported occurrences of Guiana dolphin (Sotalia guianensis Van Bénéden 1864), locally known as 'boto', and franciscana (Pontoporia blainvillei Gervais \& d'Orbigny 1844), known as 'toninha', near the Terminal 2 entrance. Since the three sailors were fishers that dealt with incidental captures of dolphins locally, their reports on Guiana dolphin and franciscana near the Açu Superport are reliable (Di Beneditto 2003; Rosa et al. 2012). They did not see interactions between these dolphins and the solitary rough-toothed dolphin. However, as dolphins' sights are not the purpose of the interviewees, it does not mean that interactions do not happen. 
When the solitary dolphin is not swimming near the supply boat, it remains close to the Terminal B-PORT, located $2.6 \mathrm{~km}$ from the Terminal 2 entrance (Figure 1). The Terminal B-PORT is one of the PUTs, operated by Brasil Port Logistica Offshore and Estaleiro Naval Ltda to provide logistics to the oil and gas operations and to make repairs on ships. The dolphin plays with the buoys and containment barriers that surround ships and tugs anchored for supply or repair, and sometimes it rubs itself against hulls (Figure 2). During the $2^{\text {nd }}$ half of 2019, an out-of-service oil platform remained anchored in coastal waters close to pier south, at $21^{\circ} 50^{\prime} 45 \mathrm{~S} ; 40^{\circ} 59^{\prime} 12 \mathrm{~W}$ (Figure 2). The solitary dolphin followed the supply boat during regular platform checking, but eventually it made the journey alone (Terminal 2-platform-Terminal 2). In February 2020, this platform was moved to open sea.

The interviewees have never swum with the solitary dolphin, touched it, or offered it food, and they were unaware of anyone who has ever done so in the Açu Superport. The diver reported that when he is underwater, the dolphin stays nearby, and sometimes it emits sounds and hits the caudal fin on divers' bodies 'just to scare, or for fun', in his own words. The diver never tried to touch the dolphin intentionally. The interviewees did not observe the solitary dolphin feeding. However, they reported plenty of fish in the Terminal 2 that can be consumed as food items.

To become a solitary dolphin, the individual undergoes many behavioral stages, named stages of sociability, as proposed by Wilke et al. (2005) (stages 1 to 4) and Nunny \& Simmonds (2019) (stages 0 and 5). Both classifications of behavioral stages share the stages 1 to 4 . Briefly, at stage 0 the dolphin is simply one seemed to be persistently on its own and may be seen in multiple locations. At stage 1, the dolphin establishes itself in a limited home range and may follow boats or approach fishing gears, but it does not approach people. At stage 2, the dolphin follows boats more regularly and it is engaged in investigating ropes, chains, buoys, being interested in people who enter the water, but it maintains a distance. At stage 3, the dolphin gets used to one or more people who have deliberately tried to habituate it, swimming, diving, touching and even holding it. At stage 4, the dolphin becomes a 'tourist attraction', and people come from further afield to see and swim with it. At this stage, the animal may start to exhibit dominant, aggressive and sexual behaviors. When a dolphin reaches the stage 5 (less common), it returns to live with conspecifics and ceases to be solitary. Wilke et al. (2005) suggest that some solitary dolphins only progress to stage 2 or 3 , such as noted for the rough-toothed dolphin in the Açu Superport. Indeed, the study case seems to be an intermediate behavior between stages 2 and 3 because the solitary rough-toothed dolphin seems to be accustomed to the interviewees, but they do not touch the dolphin intentionally.

The known records of solitary rough-toothed dolphin were from SE Brazil. Past events have been recorded, including an unreported case made by one of the authors (Siciliano, S. personal observation), which attracted the media and human attention in Praia da Costa, Espírito Santo State $\left(20^{\circ} 19^{\prime} \mathrm{S} ; 040^{\circ} 17^{\prime} \mathrm{W}\right)$. Observations of this solitary rough-toothed dolphin lasted from September 12 to September 17, 1994, at least. It was an agile dolphin, apparently in good health condition. During the observation period, it was actively chasing fish and it was often leaping and playing with floating leaves, but not approaching humans. After a week, the dolphin left the beach. No other dolphin of this species was seen nearby during the period. This episode should be noted as the first case of a solitary rough-toothed dolphin worldwide, a stage 0 according to Nunny \& Simmonds (2019).
Simultaneously to our present observations, there was a record of a solitary rough-toothed dolphin in Sepetiba Bay, southern coast of Rio de Janeiro State (Flach \& Dias 2020, Maciel et al. 2020). Observations started in November 2018 and lasted until March 29, 2020, when its carcass was found floating in Angra dos Reis Bay, which is adjacent to Sepetiba Bay, according to the National Center for Research and Conservation of Aquatic Mammals - ICMBio/ CMA (available at: https://www.facebook.com/ICMBioCMA/ posts/853742715127036/). Therefore, these two records on solitary behavior of sociable rough-toothed dolphin in coastal waters from Rio de Janeiro State $\left(21^{\circ} \mathrm{S}-23^{\circ} \mathrm{S}\right)$ were concurrent (2018-2020). The distance between the two sites (Sepetiba Bay and Açu Superport) is approximately $350-400 \mathrm{~km}$. There are other similarities between both records. Considering the stages of sociability described above, the dolphin is/was at stage 2-3. Most sightings of the roughtoothed dolphin in Sepetiba Bay were in an area where fisheries (and civilian boat traffic) are restricted because of a military base (Brazilian Navy). Thus, according to Flach \& Dias (2020) the lack of fisheries might increase the availability of prey species, attracting the solitary dolphin to this restricted area. The marine coastal waters around Açu Superport are also a fishing exclusion zone (Zappes et al. 2016), and the interviewees reported the high availability of fish in Terminal 2, where the dolphin usually stays. Therefore, it is reasonable to consider that food availability contributes/contributed to the dolphin's site fidelity in both areas.

According to the data, the solitary rough-toothed dolphin that lives in Açu Superport area is not disturbed locally and it is observed from a distance (usually from boats). The only physical interaction reported was a dolphin's initiative, and it was not encouraged by the professional diver. There is no need to alert the environmental authorities, mainly because the Açu Superport is a restricted access area, which prevents the dolphin's contact with people who could have agonistic attitudes against it. However, eventual risks to the dolphin locally could be oil spill, since the Açu superport is an oil production hub, boat collision and underwater noise levels.

\section{Acknowledgements}

We are grateful to Silvana Ribeiro Gomes (S.R. Gomes), the citizen from Atafona village that informed us about the dolphin's presence in Açu Superport, and to Aleksander Nunes, Alcinei Barreto da Silva and Jocilei Chagas da Silva (sailors) and Juliano Alcântara (diver) who sent us the videos and kindly answered the questionnaire about the solitary dolphin. This study was funded by Conselho Nacional de Desenvolvimento Científico e Tecnológico - CNPq (grants no. 305.217/2017-8 and 306.076/2019-5), Fundação Carlos Chagas Filho de Amparo à Pesquisa do Estado do Rio de Janeiro - FAPERJ (grants no. E-26/202.770/2017 and E-26/210.064/2018) and INOVA Fiocruz.

\section{Authors' Contribution}

Ana Paula Madeira Di Beneditto: contributed in the concept and design of the study, data collection and interpretation, and manuscript preparation.

Salvatore Siciliano: contributed in the data interpretation and critical revision. 


\section{Conflicts of Interest}

The authors declare that they have no conflict of interest related to the publication of this manuscript.

\section{References}

DI BENEDITTO, A.P.M. 2003. Interactions between gillnet fisheries and small cetaceans in northern Rio de Janeiro, Brazil: 2001-2002. Lat. Am. J. Aquat. Mamm. 2: 79-86.

DI BENEDITTO, A.P.M., RAMOS, R.M. \& LIMA, N.R.W. 1998. Fishing activity in northern Rio de Janeiro State (Brazil) and its relation with small cetaceans. Braz. Arch. Biol. Technol. 3: 1-7.

FLACH, L. \& DIAS, L.A. 2020. Incidence of a solitary sociable rough-toothed dolphin (Steno bredanensis) in southeast Brazil. Aquat. Mamm. 46: 93-98.

JEFFERSON, T.A. 2018. Rough-toothed dolphin Steno bredanensis. In Encyclopedia of Marine Mammals (B. Würsig, J.G.M. Thewissen \& K. Kovacs, eds). Academic Press, San Diego, p.838-840.

KISZKA, J., BAIRD, R. \& BRAULIK, G. 2019. Steno bredanensis. The IUCN Red List of Threatened Species 2019. Available at: https://www.iucnredlist. org/species/20738/50376703. Downloaded on 14 April 2020.

LODI L, MARICATO, G. 2020. Rough-toothed dolphins (Cetartiodactyla: Delphinidae) habitat use in coastal urban waters of the Southwestern Atlantic. J. Mar. Biology. Assoc. U.K. 1-9. https://doi.org/10.1017/S0025315420000132

MACIEL, I.S., MARICATO, G., MARQUI, L. ALVES, M.A.S. \& TARDIN, R.H. 2020. Home alone: solitary rough-toothed dolphin (Steno bredanensis) in residence area of Guiana dolphins (Sotalia guianensis). Aquat. Mamm. 46: 42-48.

MIYAZAKI, N. \& PERRIN, W.F. 1994. Rough-toothed dolphin Steno bredanensis (Lesson, 1828). In Handbook of Marine Mammals Vol. 5 (S.H. Ridgway \& R. Harrison, eds). Academic Press, San Diego, p. 1-21.

MONTEIRO, F., LEMOS, L.S., DE MOURA, J.F., ROCHA, R.C.C., MOREIRA, I., DI BENEDITTO, A.P.M., KEHRIG, H.A., BORDONE, I.C.A.C., SICILIANO, S., SAINT'PIERRE, T.D. \& HAUSER-DAVIS, R.A. 2019. Subcellular metal distributions and metallothionein associations in rough-toothed dolphins (Steno bredanensis) from Southeastern Brazil. Mar. Poll. Bull 146: 263-273.
MONTEIRO, F., LEMOS, L.S., DE MOURA, J.F., ROCHA, R.C.C., MOREIRA, I., DI BENEDITTO, A.P.M., KEHRIG, H.A., BORDONE, I.C.A.C., SICILIANO, S., SAINT'PIERRE, T.D. \& HAUSER-DAVIS, R.A. 2020. Total and subcellular Ti distribution and detoxification processes in Pontoporia blainvillei and Steno bredanensis dolphins from Southeastern Brazil. Mar. Poll. Bull. 153: 110975.

MÜLLER, M. \& BOSSLEY, M. 2002. Solitary bottlenose dolphins in comparative perspective. Aquat. Mamm. 28: 298-307.

NUNNY, L. \& SIMMONDS, M.P. 2019. A global reassessment of solitarysociable dolphins. Front. Vet. Sci. 5: 1-16.

RITTER, F. 2002. Behavioural observations of rough-toothed dolphins (Steno bredanensis) off La Gomera, Canary Islands (1995-2000) with special reference to their interactions with humans. Aquat. Mamm. 28: 46-59.

RODRIGUEZ, M.R. \& SUSLICK, S.B. 2009. An overview of Brazilian petroleum exploration lease auctions. Terrae: 6-20.

ROSA, G.A., ZAPPES, C.A. \& DI BENEDITTO, A.P.M. 2012. Etnoecologia de pequenos cetáceos: interações entre a pesca artesanal e golfinhos no norte do estado do Rio de Janeiro, Brasil. Biotemas 25: 293-304.

WEST, K.L., MEAD, J.G. \& WHITE, W. 2011. Steno bredanensis (Cetacea: Delphinidae). Mamm. Sci. 43:177-189.

WILKE, M., BOSSLEY, M. \& DOAK, W. 2005. Managing human interactions with solitary dolphins. Aquat. Mamm. 31: 427-433.

ZAPPES, C.A., OLIVEIRA, P.C. \& DI BENEDITTO, A.P.M. 2016. Percepção de pescadores do norte fluminense sobre a viabilidade da pesca artesanal com a implantação de megaempreendimento portuário. Bol. Inst. Pesca 42: 73-88.
Received: 20/04/2020

Revised: $22 / 07 / 2020$

Accepted: 29/07/2020

Published online: 04/09/2020 